

University of Central Florida

STARS

$1-1-2011$

\title{
Quantifying the relative contribution of the climate and direct human impacts on mean annual streamflow in the contiguous United States
}

Dingbao Wang

University of Central Florida

Mohamad Hejazi

Find similar works at: https://stars.library.ucf.edu/facultybib2010

University of Central Florida Libraries http://library.ucf.edu

This Article is brought to you for free and open access by the Faculty Bibliography at STARS. It has been accepted for inclusion in Faculty Bibliography 2010s by an authorized administrator of STARS. For more information, please contact STARS@ucf.edu.

\section{Recommended Citation}

Wang, Dingbao and Hejazi, Mohamad, "Quantifying the relative contribution of the climate and direct human impacts on mean annual streamflow in the contiguous United States" (2011). Faculty Bibliography 2010s. 2066.

https://stars.library.ucf.edu/facultybib2010/2066

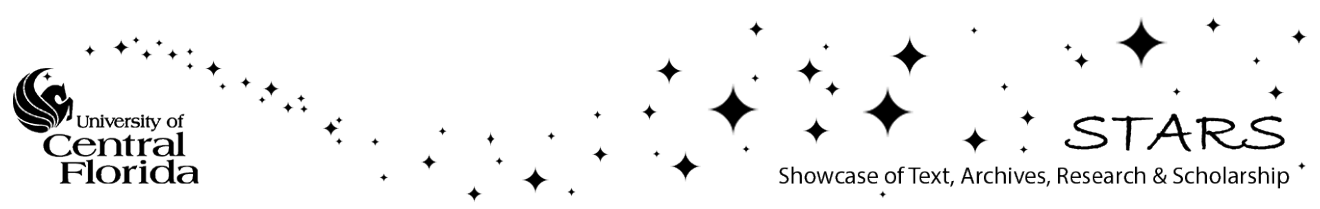




\title{
Quantifying the relative contribution of the climate and direct human impacts on mean annual streamflow in the contiguous United States
}

\author{
Dingbao Wang ${ }^{1}$ and Mohamad Hejazi ${ }^{2}$ \\ Received 28 November 2010; revised 10 July 2011; accepted 26 July 2011; published 24 September 2011.
}

[1] Both climate change and human activities are known to have induced changes to hydrology. Consequently, quantifying the net impact of human contribution to the streamflow change is a challenge. In this paper, a decomposition method based on the Budyko hypothesis is used to quantify the climate (i.e., precipitation and potential evaporation change) and direct human impact on mean annual streamflow (MAS) for 413 watersheds in the contiguous United States. The data for annual precipitation, runoff, and potential evaporation are obtained from the international Model Parameter Estimation Experiment (MOPEX), which is often assumed to only include gauges unaffected by human interferences. The data are split into two periods (1948-1970 and 1971-2003) to quantify the change over time. Although climate is found to affect MAS more than direct human impact, the results show that assuming the MOPEX data set to be unaffected by human activities is far from realistic. Climate change causes increasing MAS in most watersheds, while the direct human-induced change is spatially heterogeneous in the contiguous United States, with strong regional patterns, e.g., human activities causing increased MAS in the Midwest and significantly decreased MAS in the High Plains. The climate- and human-induced changes are found to be more severe in arid regions, where water is limited. Comparing the results to a collection of independent data sets indicates that the estimated direct human impacts on MAS in this largely nonurban set of watersheds might be attributed to several human activities, such as cropland expansion, irrigation, and the construction of reservoirs.

Citation: Wang, D., and M. Hejazi (2011), Quantifying the relative contribution of the climate and direct human impacts on mean annual streamflow in the contiguous United States, Water Resour. Res., 47, W00J12, doi:10.1029/2010WR010283.

\section{Introduction}

[2] Climate change and human activities have altered the hydrologic cycle and have exerted global-scale impacts on our environment with significant implications for water resources [Barnett et al., 2008; Milly et al., 2008; Wagener et al., 2010; Vogel, 2011]. Climate change includes the redistribution of precipitation and temperature change, which together affect streamflow discharge [Karl et al., 1996; Vörösmarty et al., 2000]. Human activities can alter the streamflow directly by affecting the hydrological processes or indirectly by disturbing the climate variables. The direct human impacts on streamflow include land use change [Schilling et al., 2010; Arrigoni et al., 2010], dam construction and reservoir operation [Rossi et al., 2009], and surface water and groundwater withdrawal and return flow [Weiskel et al., 2007; Wang and Cai, 2010]. Human impacts on climate can operate at various spatial scales. For example, at the global scale, human-induced elevated

\footnotetext{
${ }^{1}$ Department of Civil, Environmental, and Construction Engineering, University of Central Florida, Orlando, Florida, USA.

${ }^{2}$ Joint Global Change Research Institute, Pacific Northwest National Laboratory, College Park, Maryland, USA.
}

Copyright 2011 by the American Geophysical Union. 0043-1397/11/2010WR010283
$\mathrm{CO}_{2}$ emissions contribute to global warming, while at the regional scale, irrigation in the U.S. High Plains increases the rainfall and streamflow during the summer season in the Midwest [Kustu et al., 2011]. An example of local-scale impact is the urban heat island effect related to human development and urbanization.

[3] Precipitation and streamflow trends in the contiguous United States have been investigated in several recent studies. Increases in precipitation across the United States during the twentieth century have been reported by Karl and Knight [1998] and Groisman et al. [2004]. Streamflow has been increasing in the United States since at least 1940 [Lins and Slack, 1999; McCabe and Wolock, 2002]. On the basis of 400 sites in the conterminous United States measured during 1941-1999, McCabe and Wolock [2002] identified noticeable increases in annual minimum and median daily streamflow around 1970, especially in the eastern United States. They attributed streamflow increases to a step change that coincided with an increase in precipitation [McCabe and Wolock, 2002]. By developing maps of annual streamflow anomalies over the contiguous United States using streamflow records selected to reflect minimum direct impacts from human land disturbances and water diversion, Krakauer and Fung [2008] found a similar trend, i.e., increased streamflow around 1970 in concert with an increase in precipitation. Annual average flow and 
annual total precipitation have increased during the period of 1948-1997 across the eastern United States, and the trends appear to arise primarily from the increase in autumn precipitation [Small et al., 2006]. More recently, Luce and Holden [2009] examined changes to the distribution of annual streamflow from 43 gauges in the Pacific Northwest of the United States between 1948 and 2006, and they found that the mean annual flow exhibited a decreasing trend in 25 gauges and no significant trend in the remaining 18 gauges.

[4] In all of these studies, streamflow was assumed to be unaffected by human activities; detected trends of streamflow discharge were attributed to climate change alone. However, the flow of water in most rivers in the United States reflects some level of human activities [National Research Council, 2002]. Dams and diversions for irrigation may be the most cited activities, but groundwater pumping and land use change are also important factors. Recently, Arrigoni et al. [2010] found that direct anthropogenic modifications (i.e., irrigation, damming, and urbanization) of the river basins across the northern Rocky Mountains have altered the flow regimes to a much greater extent than climate change over the past 59 years. To secure a complete picture of future water resources, it is necessary to consider climate change, human systems, and hydrology in an integrated framework [Vörösmarty et al., 2000]. The separation and quantification of climate change and human impacts on streamflow is a challenge because of the complexity and interaction of climate, human, and hydrologic processes. Several recent studies have estimated the contributions of climate and human impacts on mean annual streamflow (MAS) for specific watersheds using distributed hydrologic models [Wang et al., 2009; Ma et al., 2010] and climate sensitivity or elasticity methods [ $\mathrm{Li}$ et al., 2007; Zhang et al., 2008; Ma et al., 2008; Zhao et al., 2009]. Tomer and Schilling [2009] studied the relative effects of climate change and land use change on hydrology in the Midwest on the basis of ecohydrologic plots of water versus energy use efficiency indices. Particularly, in the Upper Mississippi River Basin, Schilling et al. [2010] found that the runoff coefficient increased $32 \%$ because of land use change, i.e., increasing soybean acreage.

[5] In this paper an attempt is made to categorize streamflow change into climate-induced and direct human-induced streamflow change. The climate-induced streamflow change is caused by the alterations of precipitation and potential evaporation, which can be due to natural climate variability, global climate change, and the regional and local climate effects of human activities. The human impact on the climate includes the interdependence between evaporation $(E)$ and potential evaporation $\left(E_{p}\right)$ and the contribution from $E$ to the recycle of precipitation $(P)$ [Brutsaert and Parlange, 1998; Roderick and Farquhar, 2002; Szilagyi, 2007]. The direct human-induced streamflow change is the alteration of precipitation portioning into evaporation and runoff. On the basis of historical data during the period of 1948-2003 for 413 gauge stations across the contiguous United States, the climate-induced and direct human-induced changes of MAS are quantified, and the quantification is based on a proposed decomposition method in the Budyko framework. An order of magnitude estimate of model uncertainty is obtained through sensitivity analysis. The estimation of the direct human impact is compared with independent data such as population density, percent of urban, crop, and irrigated lands, and storage of reservoirs. The spatial patterns of climate- and direct human-induced changes to streamflow are analyzed and discussed. The results provide a comprehensive view on the climate- and direct human-induced MAS changes over the contiguous United States in the past 60 years.

\section{Methodology}

\subsection{Budyko Curves}

[6] To quantify the relative contributions of climate and direct human impacts on MAS, a hydrologic model is needed to link both climatic forcing and human impact on hydrological response. In this study, instead of applying a detailed hydrologic model to over 400 watersheds, which can be a very tedious exercise, a simple conceptual model based on the Budyko hypothesis [Budyko, 1974] is used to quantify the impact of climate and humans on MAS. Thus, this study is focused on the long-term MAS change.

[7] The water-energy balance at the watershed scale over a long-term temporal scale describes the partitioning of precipitation into evaporation and runoff. Budyko [1958] postulated that mean annual evaporation from a watershed could be determined, to first order, from rainfall and net radiation. On the basis of worldwide data on a large number of watersheds, Budyko [1974] demonstrated that the ratio of mean annual evaporation to mean annual precipitation $(E / P$, evaporation ratio) is primarily controlled by the ratio of mean annual potential evaporation to mean annual precipitation $\left(E_{p} / P\right.$, climatic dryness index $)$, as shown in Figure 1 . For watersheds with $E_{p} / P$ less than 1, the energy supply is the limiting factor for evaporation, while for watersheds with $E_{p} / P$ larger than 1 , the water supply is the limiting factor. Watersheds in different climatic regions fall at different points along the Budyko curve depending on the values of $E_{p} / P$. Observations from real watersheds are scattered around the Budyko curve because in addition to the dryness index other factors can also affect the partitioning of mean annual precipitation, such as soil water storage [Milly,

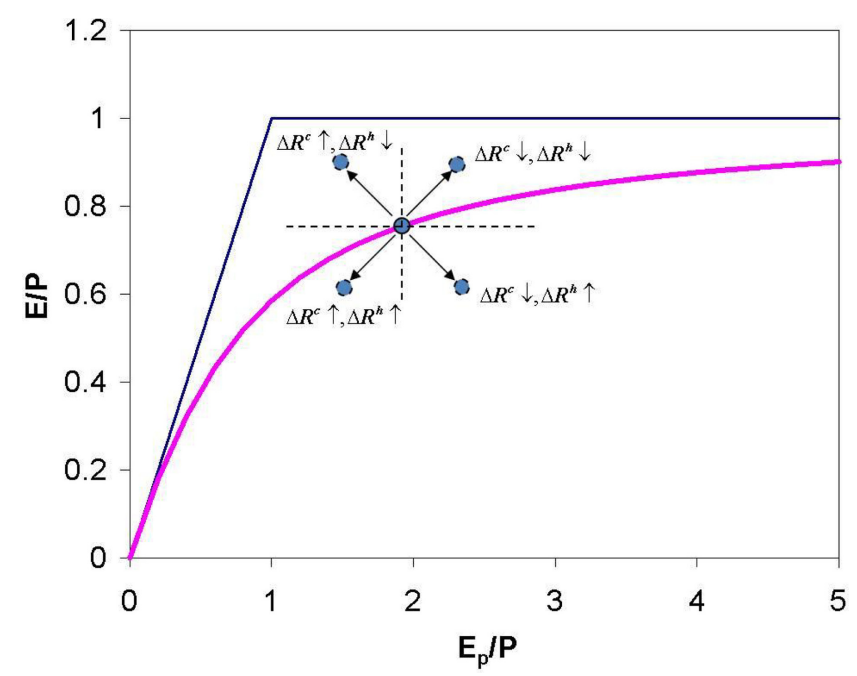

Figure 1. Budyko curve and diagram to show the direct human and climate impacts on runoff coefficient $(R=Q / P)$. 
1994], vegetation [Zhang et al., 2001; Donohue et al., 2007, 2010; Yang et al., 2009], infiltration capacity and slope [Yang et al., 2007], and rainfall seasonality and characteristics [Gerrits et al., 2009; Jothityangkoon and Sivapalan, 2009].

[8] Many researchers have studied the mean annual water balance and proposed different functional forms to represent the Budyko hypothesis [Schreiber, 1904; Ol'dekop, 1911; Turc, 1954; Pike, 1964; Fu, 1981; Milly; 1993; Zhang et al., 2001; Sankarasubramanian and Vogel, 2002; Porporato et al., 2004; Yang et al., 2008]. The sensitivity of various Budyko-type curves has been assessed by other studies [e.g., Potter and Zhang, 2009]. In this paper, the $\mathrm{Fu}[\mathrm{Fu}, 1981]$ and Turc-Pike [Turc, 1954; Pike, 1964] equations are used, and both of them are single-parameter Budyko-type curves, as shown in Table 1.

\subsection{Decomposition Method for Separating the Climate and Direct Human Impacts on MAS Change}

[9] In this paper, the direct human impact represents the change of precipitation partitioning given climate conditions, and it does not include indirect human-induced climate change. The climate change represents the contribution of mean annual potential evaporation and precipitation to the streamflow change. As a result, in Figure 1 the movement of a watershed along the horizontal direction (i.e., the change of $\left.E_{p} / P\right)$ is only driven by climate change or variability. The movement of a watershed along the vertical direction can be driven by both climate change and direct human impacts since human activities can affect runoff generation and evaporation, and climate change can affect actual evaporation and precipitation. The challenge becomes how to separate the effects of climate change and direct human impact on the vertical movement.

[10] The proposed decomposition method assumes that for a watershed without direct human impact, if the climate $\left(E_{p} / P\right)$ moves to a drier or wetter region because of climate change, the evaporation ratio $(E / P)$ will also change to a new region but will still follow the same Budyko-type curve as the prechange period. The rationale for this assumption is based on the concept of geographic zonality; that is, at less than the geological time scales, the soil and vegetation properties are dependent only on the long-term $P$ and $E_{p}$ [Dooge, 1992]. The original Budyko hypothesis is that natural watersheds follow the Budyko curve [Budyko, 1974]. The catchment properties, especially vegetation, will respond to climate variability and change through evaporation [Jones, 2011]. Therefore, with the change of climate (i.e., $E_{p} / P$ ), a watershed will evolve to a new state (i.e., change of evaporation ratio) but is still on the Budyko curve. Moreover, a watershed can move along the Budyko-type curve because of climate change only, and direct human interferences can push the watershed to move on the vertical direction, i.e., change of $E / P$ due to change of $E$. On the basis of this assumption, vertical movement of the watershed from the

Table 1. Functional Forms of Two Budyko-Type Curves

\begin{tabular}{cc}
\hline Name of Model & Functional Forms of Budyko-Type Curves \\
\hline Fu & $\frac{E}{P}=1+\frac{E_{p}}{P}-\left[1+\left(\frac{E_{p}}{P}\right)^{w}\right]^{1 / w}$ \\
Turc-Pike & $\frac{E}{P}=\left[1+\left(\frac{E_{p}}{P}\right)^{-v}\right]^{-1 / v}$ \\
\hline
\end{tabular}

Budyko-type curve can be divided into climate- and direct human-induced changes. As shown in Figure 1, there are four possible movement directions for a watershed. If the watershed moves to the top right corner, the climate and direct human interferences affect the streamflow in the same direction by decreasing the runoff coefficient $(R=$ $Q / P)$; if the watershed moves to the bottom left corner, climate and humans cause increased and decreased runoff coefficients, respectively.

[11] The proposed decomposition method is described in Figure 2. Suppose a watershed has shifted over time from point A (prechange period) to point B (postchange period) because of both climate change and direct human interferences (Figure 2). The dryness index and the evaporation ratio in the prechange period are denoted as $E_{p 1} / P_{1}$ and $E_{1} / P_{1}$, respectively. These two ratios are changed to $E_{p 2} / P_{2}$ and $E_{2} /$ $P_{2}$ in the postchange period (point B). Under climate change only, the watershed will evolve from $\left(E_{p 1} / P_{1}, E_{1} / P_{1}\right)$ to $\left(E_{p 2} /\right.$ $P_{2}, E_{2} / P_{2}$ ) along the Budyko-type curve (point $C$ ). Since the climate at points $\mathrm{B}$ and $\mathrm{C}$ is same, the precipitation at point $\mathrm{C}$ is $P_{2}$. Thus, climate change causes both horizontal and vertical shifts, i.e., from $E_{p 1} / P_{1}$ to $E_{p 2} / P_{2}$ on the horizontal direction and from $E_{1} / P_{1}$ to $E_{2}^{\prime} / P_{2}$ on the vertical direction; direct human interferences cause a vertical change from $E_{2}^{\prime} / P_{2}$ to $E_{2} / P_{2}$. For the case shown in Figure 2, the contribution of the direct human impact counteracts the vertical component attributed to the climate change impact, and the overall vertical change caused by both climate and direct human impacts is from $E_{1} / P_{1}$ to $E_{2} / P_{2}$.

[12] The climate change impact can induce both horizontal and vertical components, and both components can affect streamflow, but direct human interferences only can induce a vertical component. Thus, the contribution of direct human interferences to streamflow change is computed first. For long-term annual average, the soil water storage change can be ignored, and the streamflow is a function precipitation and evaporation ratio:

$$
Q=P(1-E / P)
$$

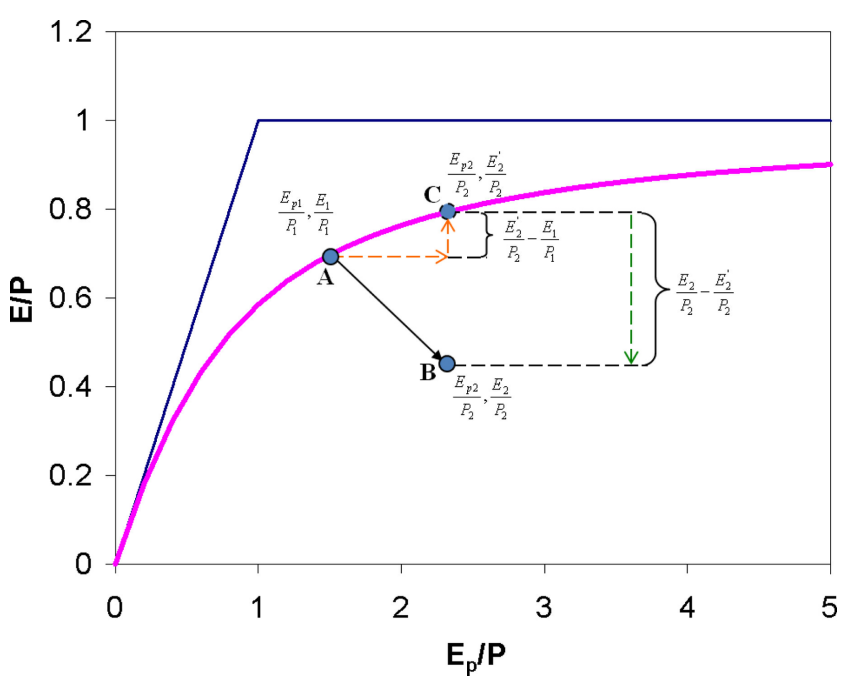

Figure 2. Decomposition method to quantify the direct human and climate contributions to the mean annual streamflow change. 
Similarly, the direct human contribution to streamflow change can be computed by

$$
\Delta Q^{h}=P_{2}\left(E_{2}^{\prime} / P_{2}-E_{2} / P_{2}\right),
$$

where $\Delta Q^{h}$ is the magnitude of the direct human-induced change of streamflow. The climate change contribution to streamflow change can be obtained by subtracting the human-induced change from the total streamflow change:

$$
\Delta Q^{c}=\Delta Q-\Delta Q^{h},
$$

where $\Delta Q^{c}$ is the climate-induced change of streamflow. Both $\Delta Q^{h}$ and $\Delta Q^{c}$ can be positive or negative. $\Delta Q$ is the total streamflow change and is computed by

$$
\Delta Q=Q_{2}-Q_{1} .
$$

[13] Given annual precipitation, streamflow, and potential evaporation data, the procedures for computing the contribution of climate change and direct human interferences to the MAS change are as follows.

[14] 1. The mean annual evaporation is calculated by assuming zero storage change, i.e., $E_{1}=P_{1}-Q_{1}$ and $E_{2}=$ $P_{2}-Q_{2}$. The mean annual values of $E_{1} / P_{1}$ and $E_{p 1} / P_{1}$ for the prechange period and $E_{2} / P_{2}$ and $E_{p 2} / P_{2}$ for the postchange period are computed.

[15] 2. This study is focused on the change between the two periods. The watersheds in the prechange period are not natural. Thus, the prechange watersheds are not on the same Budyko-type curve. Recall that the shapes of Budyko-type curves depend on the physical properties of watersheds, such as soil properties, vegetation type and coverage, and topography [e.g., Milly, 1994; Zhang et al., 2001; Yang et al., 2007; Yokoo et al., 2008]. Therefore, a single-parameter Budyko-type curve is used, and the parameter is calibrated to the prechange period; that is, separate Budyko curves are fitted for each watershed.

[16] 3. The evaporation ratio due to climate change only $\left(E_{2}^{\prime} / P_{2}\right)$ is computed on the basis of the calibrated Budykotype curve in step 2 corresponding to the observed dryness index under the postchange condition $\left(E_{p 2} / P_{2}\right)$. For the Budyko curve that is fixed, $E_{1} / P_{1}$ may not be on the curve exactly, but $E_{2}^{\prime} / P_{2}$ is assumed to be on the Budyko curve corresponding to $E_{p 2} / P_{2}$ in the decomposition method.

[17] 4 . The streamflow change due to direct human interferences is computed by equation (2).

[18] 5. The climate-induced change of streamflow $\left(\Delta Q^{c}\right)$ can be computed by equation (3). It can also be computed directly from the postchange condition without direct human interferences, i.e., $\Delta Q^{c}=Q_{2}^{\prime}-Q_{1}$. Given negligible storage change for mean annual water balance, $Q_{2}^{\prime}=$ $P_{2}-E_{2}^{\prime}=P_{2}\left(1-\frac{E_{2}^{\prime}}{P_{2}}\right)$. Therefore, one obtains

$$
\Delta Q^{c}=P_{2}\left(1-E_{2}^{\prime} / P_{2}\right)-Q_{1} .
$$

[19] Recently, several related studies have quantified the climate and direct human contributions to the streamflow change on the basis of the Budyko framework [ Li et al.,
2007; Zhang et al., 2008; Ma et al., 2008; Zhao et al., 2009]. In these studies, the climate contribution to the streamflow change is computed by the sensitivity or elasticity method, which is based on the perturbations in precipitation and potential evaporation. The climate-induced change on MAS is determined by

$$
\Delta Q^{c}=\beta \Delta P+\gamma \Delta E_{p},
$$

where $\beta$ and $\gamma$ are the sensitivity coefficients of streamflow to precipitation and potential evaporation, respectively, i.e., $\beta=\partial Q / \partial P$ and $\gamma=\partial Q / \partial E_{p}$. The two sensitivity coefficients can be obtained by the partial derivatives on the basis of the functional form of Budyko curve. For example, if Fu's equation is used, $\beta=P_{1}^{w-1}\left(E_{p 1}{ }^{w}+P_{1}^{w}\right)^{(1 / w)-1}$ and $\gamma=E_{p 1}{ }^{w-1}\left(E_{p 1}{ }^{w}+P_{1}^{w}\right)^{(1 / w)-1}-1[$ Ma et al., 2008]; then

$$
\begin{aligned}
\Delta Q^{c}= & P_{1}^{w-1}\left(E_{p 1}^{w}+P_{1}^{w}\right)^{\frac{1}{w}-1}\left(P_{2}-P_{1}\right) \\
& +\left[E_{p 1}{ }^{w-1}\left(E_{p 1}{ }^{w}+P_{1}^{w}\right)^{\frac{1}{w}-1}-1\right]\left(E_{p 2}-E_{p 1}\right) .
\end{aligned}
$$

After computing $\Delta Q^{c}$, the direct human impact is the difference between the total observed change in streamflow and streamflow change attributed to climate change, i.e., $\Delta Q^{h}=\Delta Q-\Delta Q^{c}$.

[20] For the decomposition method, if Fu's equation is used, substituting Fu's equation into equation (5), one obtains

$$
\Delta Q^{c}=\left(P_{2}^{w}+E_{p 2}{ }^{w}\right)^{\frac{1}{w}}-E_{p 2}-Q_{1} .
$$

The decomposition method treats the climate dryness index as one component in equation (5), while in the sensitivity method the individual sensitivities of precipitation and potential evaporation to streamflow are computed separately. Comparing equations (7) and (8) for the case of Fu's equation, for the sensitivity method, $\Delta Q^{c}$ is a function of precipitation and potential evaporation during prechange and postchange periods, while for the decomposition method, $\Delta Q^{c}$ is a function of streamflow during the prechange period and the precipitation and potential evaporation during the postchange period. It also should be noted that both direct human and climate contributions to streamflow change can be estimated independently in the decomposition method, i.e., equations (2) and (5), respectively, while for the sensitivity method, the direct human impact results from the residual after subtracting the climate impact.

\subsection{Comparing the Results from the Decomposition Method With Published Data}

[21] The climate- and direct human-induced percentage changes of annual streamflow have been estimated for specific watersheds in several studies [Zhao et al., 2009; Wang et al., 2009; Zhang et al., 2008; Ma et al., 2008; Li et al., 2007] using the climate sensitivity method:

$$
\begin{aligned}
& C=100\left(\Delta Q^{c} / \Delta Q\right), \\
& H=100\left(\Delta Q^{h} / \Delta Q\right) .
\end{aligned}
$$

The watersheds and their estimated climate $(C)$ and direct human $(H)$ impacts on mean annual streamflows from these studies are shown in Table 2. Both climate and direct 
Table 2. Human- and Climate-Induced Percentage Change on Annual Streamflow Compared Between Published Data and the Decomposition Method ${ }^{\mathrm{a}}$

\begin{tabular}{|c|c|c|c|c|c|}
\hline \multirow[b]{2}{*}{ Watershed } & \multicolumn{2}{|c|}{ Zhao et al. [2009] } & \multicolumn{2}{|c|}{ Decomposition } & \multirow[b]{2}{*}{$\Delta H$} \\
\hline & $H$ & $C$ & $H$ & $C$ & \\
\hline Huangheyan & 93 & 7 & 94.9 & 5.1 & 1.9 \\
\hline Jimai & 85 & 15 & 87.0 & 13.0 & 2.0 \\
\hline Maqu & 51 & 49 & 54.1 & 45.9 & 3.1 \\
\hline Jungong & 44 & 56 & 46.4 & 53.6 & 2.4 \\
\hline Tangnaihai & 42 & 58 & 44.5 & 55.5 & 2.5 \\
\hline Guide & 47 & 53 & 49.9 & 50.1 & 2.9 \\
\hline Xunhua & 48 & 52 & 50.5 & 49.5 & 2.5 \\
\hline Xiaochuan & 49 & 51 & 52.0 & 48.0 & 3.0 \\
\hline Lanzhou & 52 & 48 & 54.8 & 45.2 & 2.8 \\
\hline
\end{tabular}

\begin{tabular}{|c|c|c|c|c|c|}
\hline \multirow[b]{2}{*}{ Watershed } & \multicolumn{2}{|c|}{ Zhang et al. [2008] } & \multicolumn{2}{|c|}{ Decomposition } & \multirow[b]{2}{*}{$\Delta H$} \\
\hline & $H$ & $C$ & $H$ & $C$ & \\
\hline Huangfu & 79 & 21 & 80.5 & 19.5 & 1.5 \\
\hline Gushan & 61 & 39 & 60.0 & 40.0 & -1.0 \\
\hline Kuye & 78 & 22 & 72.4 & 27.6 & -5.6 \\
\hline Jialu & 63 & 37 & 62.3 & 37.7 & -0.7 \\
\hline Wuding & 57 & 43 & 60.7 & 39.3 & 3.7 \\
\hline Shiwang & 43 & 57 & 33.0 & 67.0 & -10.0 \\
\hline Xinshui & 45 & 55 & 28.5 & 71.5 & -16.5 \\
\hline Sanchuan & 70 & 30 & 63.6 & 36.4 & -6.4 \\
\hline Weifen & 43 & 57 & 50.4 & 49.6 & 7.4 \\
\hline Zhujia & 55 & 45 & 57.7 & 42.3 & 2.7 \\
\hline \multirow[t]{2}{*}{ CSHC } & 54 & 46 & 51.8 & 48.2 & -2.2 \\
\hline & \multicolumn{2}{|c|}{ Ma et al. [2008] } & \multicolumn{2}{|c|}{ Decomposition } & \\
\hline Watershed & $H$ & C & $H$ & C & $\Delta H$ \\
\hline Huangfu & 12.1 & 87.9 & 12.0 & 88.0 & -0.1 \\
\hline Gushan & 35.5 & 64.5 & 35.7 & 64.3 & 0.2 \\
\hline Kuye & 22.1 & 77.9 & 22.7 & 77.3 & 0.6 \\
\hline Jialu & 23.1 & 76.9 & 23.8 & 76.2 & 0.7 \\
\hline
\end{tabular}

\begin{tabular}{|c|c|c|c|c|c|}
\hline \multirow[b]{2}{*}{ Watershed } & \multicolumn{2}{|c|}{ Li et al. [2007] } & \multicolumn{2}{|c|}{ Decomposition } & \multirow[b]{2}{*}{$\Delta H$} \\
\hline & $H$ & C & $H$ & C & \\
\hline \multirow[t]{2}{*}{ Wuding } & 84.3 & 15.7 & 62.8 & 37.2 & -21.5 \\
\hline & \multicolumn{2}{|c|}{ Wang et al. [2009] ${ }^{\mathrm{b}}$} & \multicolumn{2}{|c|}{ Decomposition } & \\
\hline Watershed & $H$ & $C$ & $H$ & $C$ & $\Delta H$ \\
\hline Chao & 68.6 & 31.4 & 64.7 & 35.3 & -3.9 \\
\hline Bai & 70.4 & 29.6 & 52.8 & 47.2 & -17.6 \\
\hline
\end{tabular}

${ }^{\mathrm{a}} H=100\left(Q^{h} / \Delta Q\right)$, and $C=100\left(\Delta Q^{c} / \Delta Q\right) . \Delta H$ is the difference of human- and climate-induced percentage change.

${ }^{\mathrm{b}} \mathrm{On}$ the basis of simulation models. Other methods from the literature are based on the climate sensitivity method.

human interferences reduce streamflow for all of the watersheds in Table 2. Fu's equation [Fu, 1981], shown in Table 1, is used for the decomposition method for these watersheds, and the estimated percentage of climate and direct human contributions to streamflow change by the decomposition method is also shown in Table 2 .

[22] From Table 2, the results based on the decomposition method are close to the estimation by Zhao et al. [2009] for nine watersheds, and the difference of direct human contribution ranges between $1.9 \%$ and $3.1 \%$. For the 11 watersheds in the work of Zhang et al. [2008], the values of $H$ are $-10 \%$ for Shiwang watershed, $-16.5 \%$ for
Xinshui watershed, and $7.4 \%$ for Weifen watershed. In the estimation by Zhang et al. [2008], the climate contribution to the reduced streamflow in the Weifen watershed is estimated as $57 \%$, which is the highest among all the 11 watersheds, but the precipitation decrease in the Weifen watershed $\left(-1.1 \mathrm{~mm} \mathrm{yr}^{-1}\right)$ is much more modest compared to the Shiwang and Xinshui watersheds $(-2.9$ and -4.3 $\mathrm{mm} \mathrm{yr}^{-1}$, respectively). The authors recognized this puzzling result but did not give an explanation. On the basis of the decomposition method, the climate contribution is $49.6 \%$ in the Weifen watershed but $67.0 \%$ and $71.5 \%$ for the Shiwang and Xinshui watersheds, respectively, suggesting that the estimation by the decomposition method is more reasonable. Both the decomposition method and the sensitivity method of Ma et al. [2008] are based on Fu's equation, and the difference between them is minimal. The difference of direct human contribution $(\Delta H)$ is between $-0.1 \%$ and $0.7 \%$. The difference of direct human contribution between the decomposition method and the estimation by $L i$ et al. [2007] is $-21.5 \%$, the highest among all the selected watersheds. Compared with the results from the water balance model by Wang et al. [2009], the direct human contribution by the decomposition method is 3.9\% less for the Chao River and 17.6\% less for the Bai River.

\section{Application to the Watersheds in the Contiguous United States}

[23] In this section, the proposed decomposition method is utilized to assess the climate and direct human impacts on MAS at selected watersheds in the contiguous United States. The data sets for the assessment and validation are described first, then the results are presented, and the assessed contribution of direct human impact is compared with independent data sets of human activities, such as population density, urbanization, cropland area, irrigation area, and reservoirs. The spatial patterns of both climate and direct human impacts are discussed.

\subsection{Data}

[24] The international Model Parameter Estimation Experiment (MOPEX) data set is used in this study. The data set is described by Duan et al. [2006] and can be downloaded from ftp://hydrology.nws.noaa.gov/. This data set includes mean areal precipitation, potential evaporation, daily streamflow, and daily maximum and minimum air temperature for 432 watersheds with an adequate number of precipitation gauges. The daily precipitation, potential evaporation, and discharge are aggregated to the annual values (1948-2003) for the analysis in this study. Because of the missing data for some watersheds, 413 watersheds are selected for the quantification of climate and direct human impacts on mean annual streamflow change. The precipitation data are from the National Climate Data Center and the Natural Resources Conservation Service SNOTEL network. Most of the streamflow data are included in the Hydroclimatic Data Network (HCDN) [Slack et al., 1993], which includes only gauges believed to be unaffected by upstream regulations. That is not the case as follows from this study. The HCDN data set has been used in many studies [e.g., Sankarasubramanian et al., 2001; 
McCabe and Wolock, 2002; Small et al., 2006; Krakauer and Fung, 2008; Luce and Holden, 2009].

[25] Statistical tests, such as Pettitt's test, on streamflow have been used to identify significant change points in time [Zhang et al., 2008; Ma et al., 2008], and then the change of mean annual streamflow from the prechange period to the postchange period is computed. For the purpose of cross comparison among watersheds and their spatial patterns, the data set is split in to two periods at the same change point. Moreover, it has been documented that streamflow exhibits an upward (increasing) step change around 1970 and that the observed streamflow change is in concert with an increase in precipitation in the contiguous United States [McCabe and Wolock, 2002; Small et al., 2006; Krakauer and Fung, 2008]. Thus, changes of mean annual precipitation, evaporation, and streamflow from the preperiod of 1948-1970 to the postperiod of 1971-2003 are calculated for each of the 413 selected watersheds.

[26] To validate the results of the proposed methodology, a set of independent data sets are compiled, including population density at the county scale, percent of urbanization, land coverage, percent of irrigated land, and average reservoir storage, at various spatial resolutions (Table 3). All covering the entire contiguous United States and using the boundaries of all 413 watersheds to intersect with the ArcGIS layers of relevant variables, the average or total value of all grids (or points) located within the boundary of each watershed are computed to estimate population density, percent of urban land, percent of cropland, percent of irrigated land, and average reservoir storage (Figure 3). For example, the population data, available at the county scale, are converted to population density by dividing the total population by the total area in square miles for each county and then by converting all polygons to raster data and finally by averaging the density values of all grids that lie within the boundary of each of the 413 watersheds. Unfortunately, these are reflective of conditions at a particular point in time rather than a relative change between the two tested time periods (Table 3). However, assuming somewhat natural conditions in the early period, current conditions can be considered as a reasonable estimate of the relative change. This information will be used as an independent data set to validate the results, especially with respect to the estimated direct human impact on MAS.

\subsection{Results}

[27] The first step is to compute the parameter of the Budyko type curve (i.e., $w$ or $v$ in Table 1) for each watershed. Then climate- and direct human-induced MAS change are computed. To compare the results between watersheds, the climate- and direct human-induced percentage changes relative to the prechange period are computed:

$$
\begin{aligned}
& \Delta Q^{c \%}=100\left(\Delta Q^{c} / Q_{1}\right), \\
& \Delta Q^{h \%}=100\left(\Delta Q^{h} / Q_{1}\right) .
\end{aligned}
$$

Figure 4 shows a cross comparison of $\Delta Q^{h \%}$ and $\Delta Q^{c \%}$ between the $\mathrm{Fu}$ and Turc-Pike equations. The estimations by $\mathrm{Fu}$ and Turc-Pike match reasonably well, except for some watersheds around $\Delta Q^{h} \%=0$. In the following, only the results based on Fu's equation are presented.

[28] Figure 5 shows $\Delta Q^{h \%}$ versus $\Delta Q^{c} \%$ for each watershed. The direct human impact has induced a wide range of both increasing and decreasing shifts in MAS. Climate change, however, has mainly attributed to an increase in mean streamflow in most of the selected 413 watersheds. When averaging across all the watersheds (Table 4) and given the direct impact of human activities on annual streamflow is mixed with almost equal numbers of watersheds with opposite (i.e., increasing or decreasing) induced changes (Figure 5), there is no clear trend to whether direct human impact has caused more or less annual streamflow change. But climate has induced an increase in annual streamflow by $+18 \%$. When comparing the absolute impact of climate and direct human activities on streamflow $\left(\left|\Delta Q^{h \%}\right|\right.$ and $\left.\left|\Delta Q^{c \%}\right|\right)$, climate exhibits a stronger impact (Table 4). This finding is expected given that the MOPEX data set used in this study was collected for watersheds with minimal human activities [Duan et al., 2006]. However, $\mid \Delta Q^{h \%}$ | (i.e., $16 \%$ ) is only slightly smaller than $\left|\Delta Q^{c} \%\right|$ (i.e., 18\%). This signifies two important messages: (1) although climate change is found to induce greater impact on MAS than direct human interferences, this conclusion is likely to change if a more comprehensive set of watersheds in the contiguous United States (in which human interferences are more significant) has been included or if human contribution to climate change is accounted for as part of the human impact on MAS, and (2) assuming that the selected set of watersheds has negligible human-induced changes is questionable, and this suggests that the impact of human interferences to hydrology is far more reaching and that the assumption of human-free watersheds is less likely in the real world.

[29] For example, most of the selected watersheds exhibited a negligible percentage of urbanization (Figure 3b), an implicit assumption about the MOPEX data set. However, the fact that these watersheds have undergone minimal urbanization does not rule out the direct impact of humans on MAS through other means, i.e., irrigation, cropland

Table 3. List of Variables Used as a Validation of the Results of Direct Human Impacts on Mean Annual Streamflows

\begin{tabular}{lcccc}
\hline \multicolumn{1}{c}{ Item } & Unit & Spatial Resolution & Period Coverage & Source \\
\hline Population density & persons/mile & county scale & 1990 & U.S. Geological Survey [2010] \\
Urban land & $\%$ & grid scale $(\sim 9 \mathrm{~km})$ & 2001 & U.S. Geological Survey [2001] \\
Cropland & $\%$ & grid scale $(\sim 1 \mathrm{~km})$ & $1981-1994$ & NOAA \\
Irrigated land & $\%$ & grid scale $(\sim 9 \mathrm{~km})$ & 2000 & Siebert et al. [2007] \\
Average reservoir storage & acre-feet & point scale & 1815-2002 & National Atlas of the United States [2006] \\
\hline
\end{tabular}

${ }^{a}$ U.S. MOPEX Data Set: Fractional coverage of each vegetation type according to the University of Maryland (UMD) vegetation classification system (ftp://hydrology.nws.noaa.gov/pub/gcip/mopex/US_Data/Basin_Characteristics/Vegetation/UMD/, accessed in March 2011).

${ }^{b}$ Year in which the reservoir's construction was completed. 

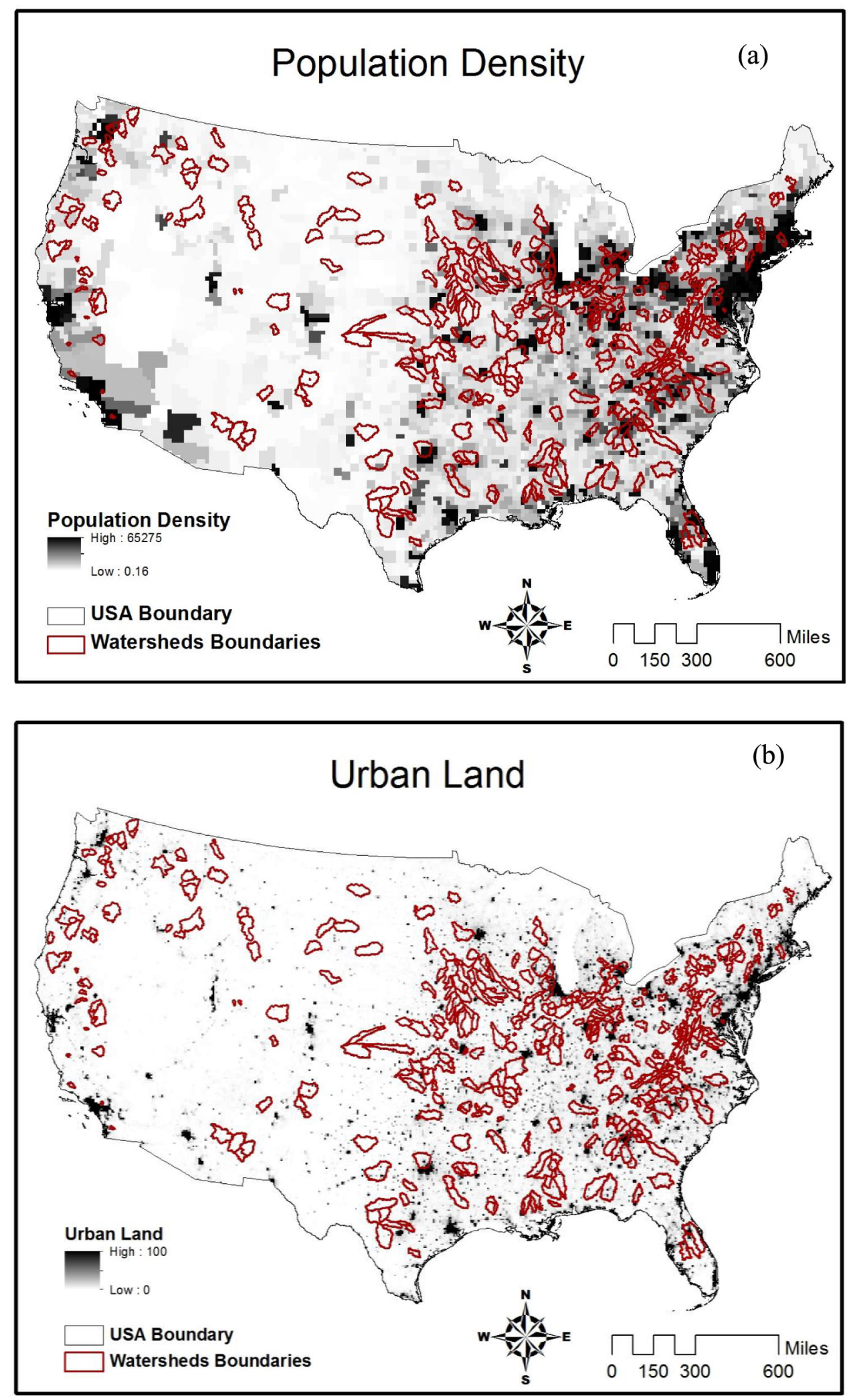

Figure 3. Spatial coverage of exogenous information used as a validation of the direct human impacts on mean annual streamflows. 

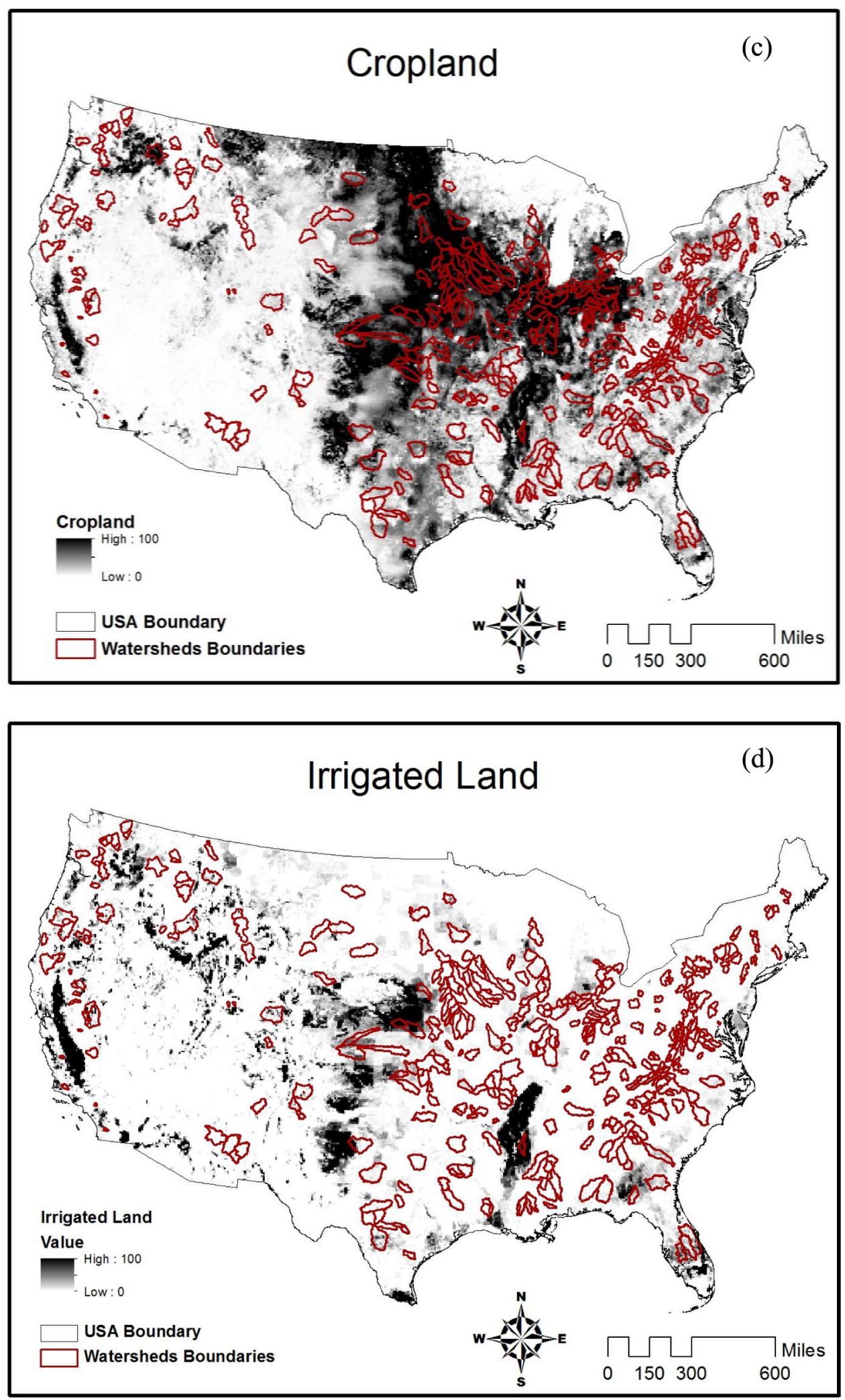

Figure 3. (continued) 


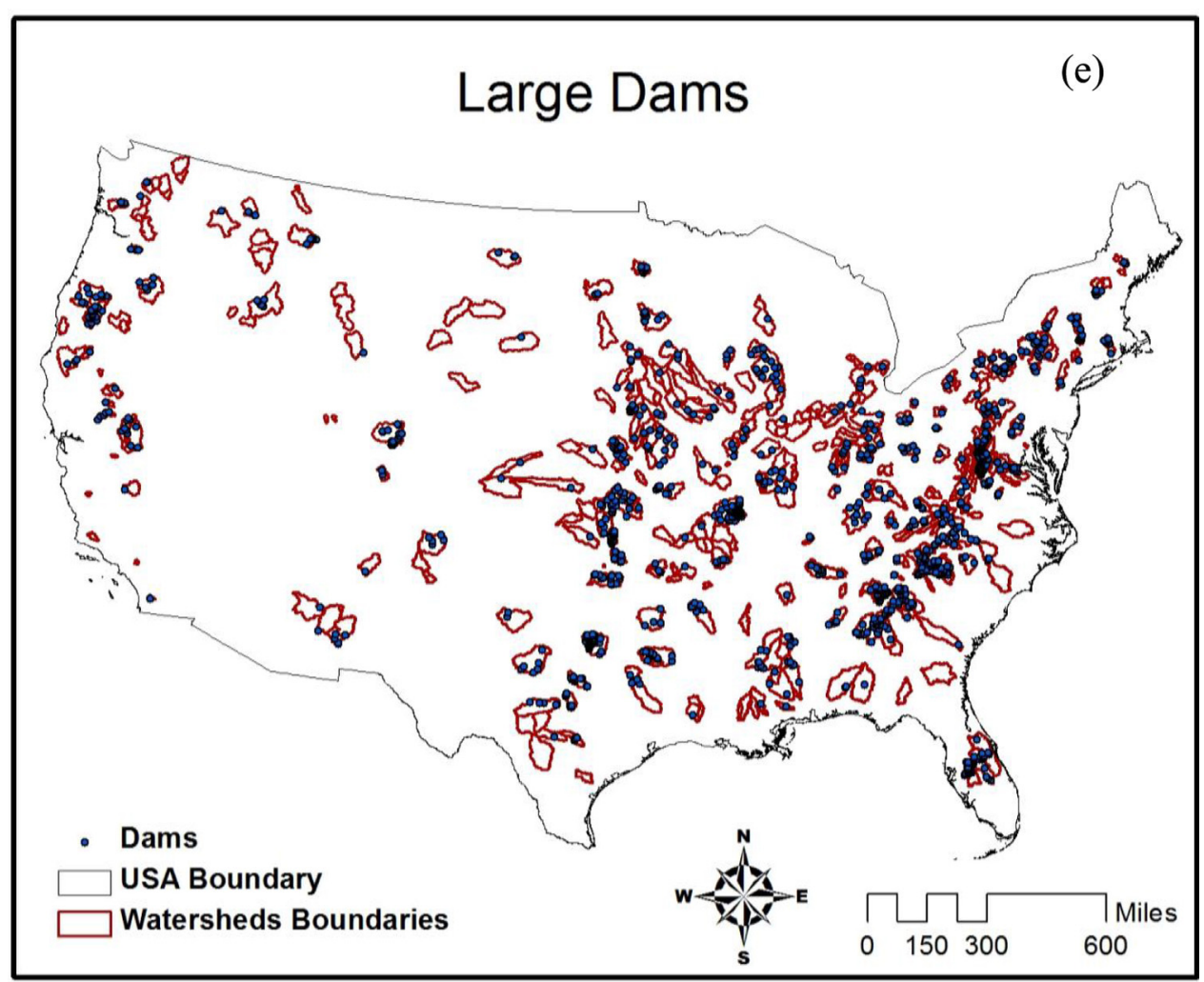

Figure 3. (continued)
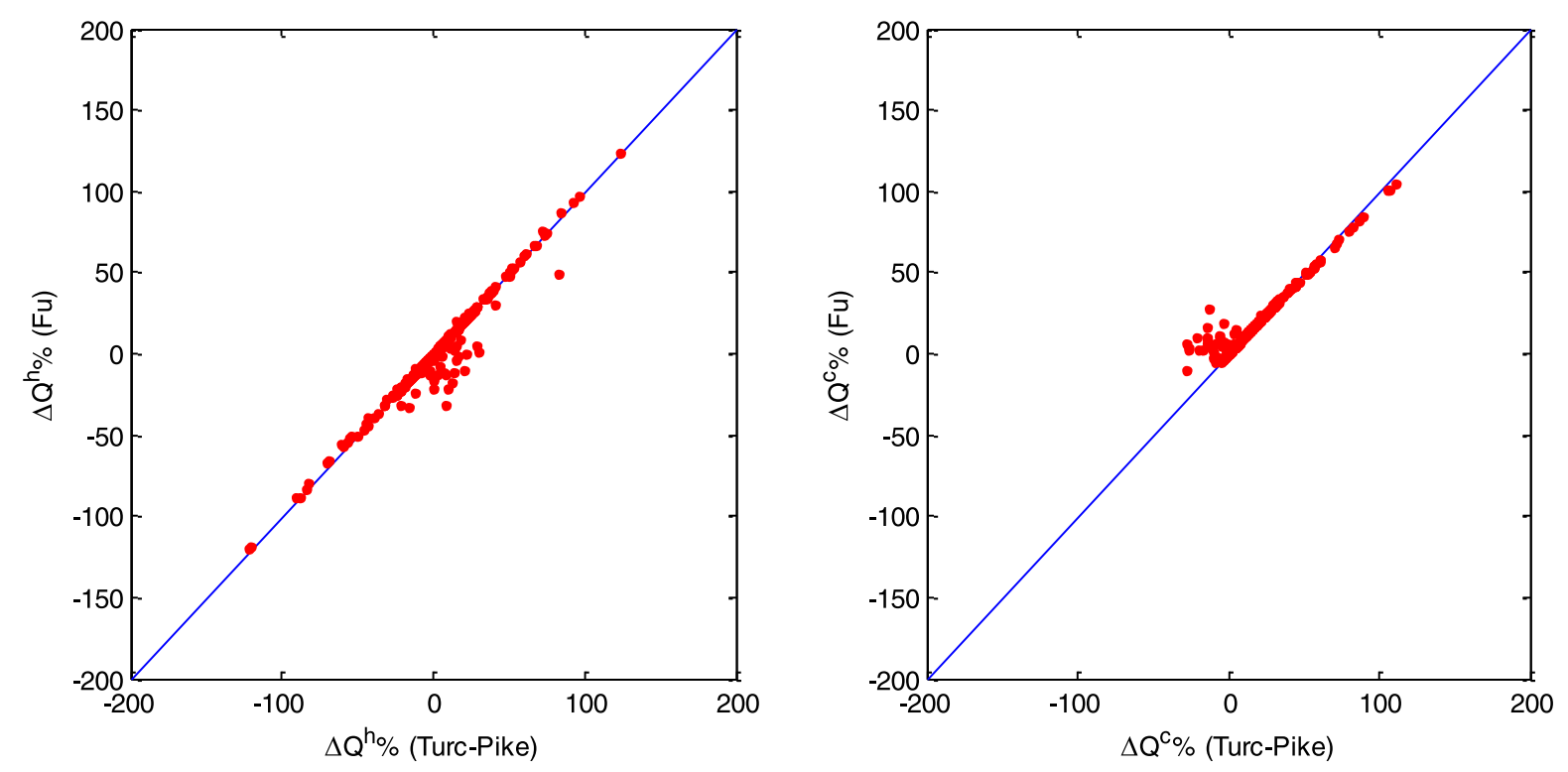

Figure 4. The cross comparison of estimated climate- and direct human-induced streamflow change between $\mathrm{Fu}$ and Turc-Pike equations. 


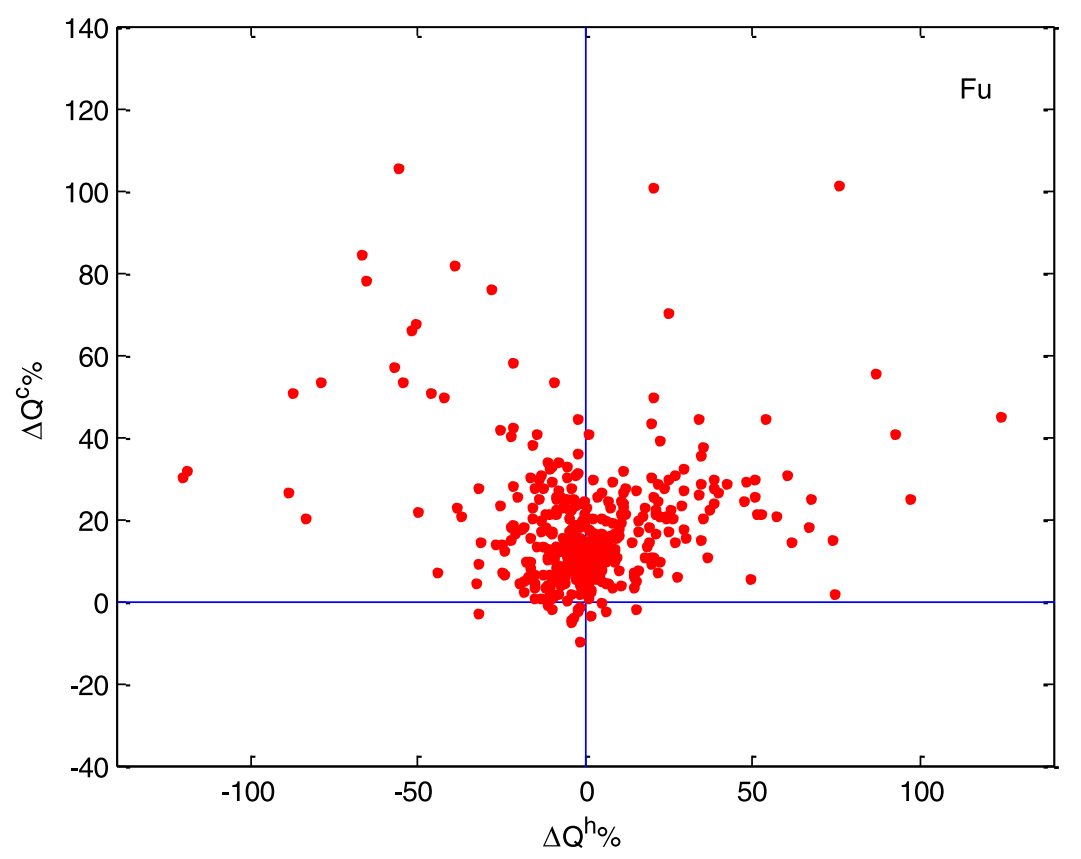

Figure 5. The climate-induced versus direct human-induced streamflow changes by percentage for the 413 watersheds.

expansion, increased municipal water consumption, and increased evaporation due to dam construction and hydropower generation. To build upon this hypothesis, the watersheds are grouped into seven categories (Table 5) on the basis of the estimated relative change in streamflow due to direct human impacts only. Then, the corresponding population density, urban land percent, cropland percent, irrigated land percent, and average reservoir storage values are computed for each of the categories (Table 5).

[30] As shown in Figure 6, the validation data indicate that on average, the level of estimated direct human impact on streamflow is proportional to population density and percent of urban and cropland areas and inversely proportional to the percent of irrigated land and the average storage of reservoirs in the watersheds. These relations are intuitive and a necessary step to validate the proposed decomposition methodology. For example, watersheds with large population density and urban land percent values are likely to have experienced an increase in mean annual streamflow because of increasing imperviousness (reduced infiltration). Watersheds with a larger fraction of cropland could easily lead to less or more water consumption and thus more or less MAS. For instance, if more irrigation is being applied, then more water is likely to be consumed by crops than if no crops

Table 4. Minimum, Maximum, Mean, and Coefficient of Variance (CV) of $\Delta Q^{h_{\%}} \%, \Delta Q^{c_{\%}} \%, \mid \Delta Q^{h_{0}} \%$, and $\left|\Delta Q^{c_{0}} \%\right|$ Among the 413 Watersheds

\begin{tabular}{lccc}
\hline & Minimum, Maximum & Mean & CV \\
\hline$\Delta Q^{h \%}$ & {$[-120.2,124.1]$} & 0.6 & 44.8 \\
$\Delta Q^{c \%}$ & {$[-9.5,105.3]$} & 18.0 & 0.9 \\
$\left|\Delta Q^{h \%}\right|$ & {$[0.02,124.1]$} & 16.0 & 1.2 \\
$\left|\Delta Q^{c \%}\right|$ & {$[0.2,105.3]$} & 18.2 & 0.8 \\
\hline
\end{tabular}

existed originally (e.g., grass and forest). Assuming rain-fed crops are dominant, whether, annually, crops are bigger or smaller consumers of water than the original land cover dictates the sign of the change. Zhang and Schilling [2006] attributed the increasing trend of annual low flows in the Mississippi River to land cover change. In another study, Schilling et al. [2008] stated that agricultural development in the Midwest during the last century has converted perennial grasslands to annual row crops. Perennial vegetation transpires throughout the spring, summer, and autumn seasons, while the majority of the transpiration from row crops occurs during the summer. As a result, the annual ET loss has a decreasing trend, which, in turn, increases the base flow and annual flow [Schilling et al., 2008]. Thus, increases in cropland areas in the selected watersheds are likely to increase MAS given reduced evapotranspiration during the nongrowing seasons when the land is fallow. Our validation results exhibit a similar trend. Moreover, watersheds with large shares of irrigated land are likely to have enhanced evapotranspiration, thus leading to lower mean annual streamflows (Figure 6d). Last, augmenting rivers by constructing dams increases both the human water consumption (e.g., water supply, hydropower via higher evaporations, and irrigation) and water losses due to enhanced evaporations from the larger surface areas of impounded water bodies. Thus, watersheds with larger reservoir storage are likely to reflect a reduction in MAS. Although a direct validation of the estimated direct human impacts is not possible, the meaningful relations between the estimated humaninduced MAS change and the set of external validation data sets show the consistency of the proposed methodology.

[31] The spatial distribution of the estimated climateand direct human-induced streamflow change are analyzed. Figure 7 shows the spatial distribution of the relative magnitude of climate and direct human factors. The red 
Table 5. Comparison of the Estimated $\Delta Q^{h_{\%}} \%$ With External Validation Data, Namely, Population Density, Urban Land, Cropland, Irrigated Land, and Average Reservoir Storage

\begin{tabular}{lccccccc}
\hline \multicolumn{1}{c}{$\Delta Q^{h_{0}}$ Range } & $\begin{array}{c}\Delta Q^{h_{0}} \\
\text { Mean }\end{array}$ & $\begin{array}{c}\text { Count of } \\
\text { Watersheds }\end{array}$ & $\begin{array}{c}\text { Population Density } \\
\left.\text { (persons/mile }{ }^{2}\right)\end{array}$ & $\begin{array}{c}\text { Urban Land } \\
(\%)\end{array}$ & $\begin{array}{c}\text { Crop Land } \\
(\%)\end{array}$ & $\begin{array}{c}\text { Irrigated Land } \\
(\%)\end{array}$ & $\begin{array}{c}\text { Reservoir Storage } \\
\text { (acre-feet) }\end{array}$ \\
\hline$\Delta Q^{h_{\%}}<-20 \%$ & -44 & 42 & 33 & 0.7 & 12 & 1.9 & 77,508 \\
$-20 \%<\Delta Q^{h_{0}}<-10 \%$ & -14 & 57 & 127 & 1.6 & 9 & 2.6 & 74,097 \\
$-10 \%<\Delta Q^{h_{\%}}<-1 \%$ & -5 & 117 & 92 & 1.8 & 11 & 0.5 & 94,182 \\
$-1 \%<\Delta Q^{h_{0}}<1 \%$ & 0 & 27 & 113 & 2.1 & 17 & 0.1 & 49,121 \\
$1 \%<\Delta Q^{h_{0}}<10 \%$ & 5 & 73 & 108 & 2.8 & 28 & 0.9 & 36,952 \\
$10 \%<\Delta Q^{h_{0}}<20 \%$ & 15 & 33 & 183 & 2.9 & 44 & 0.8 & 36,275 \\
$\Delta Q^{h_{\%}}>20 \%$ & 40 & 64 & 112 & 1.5 & 50 & 1.5 & 31,396 \\
\hline
\end{tabular}
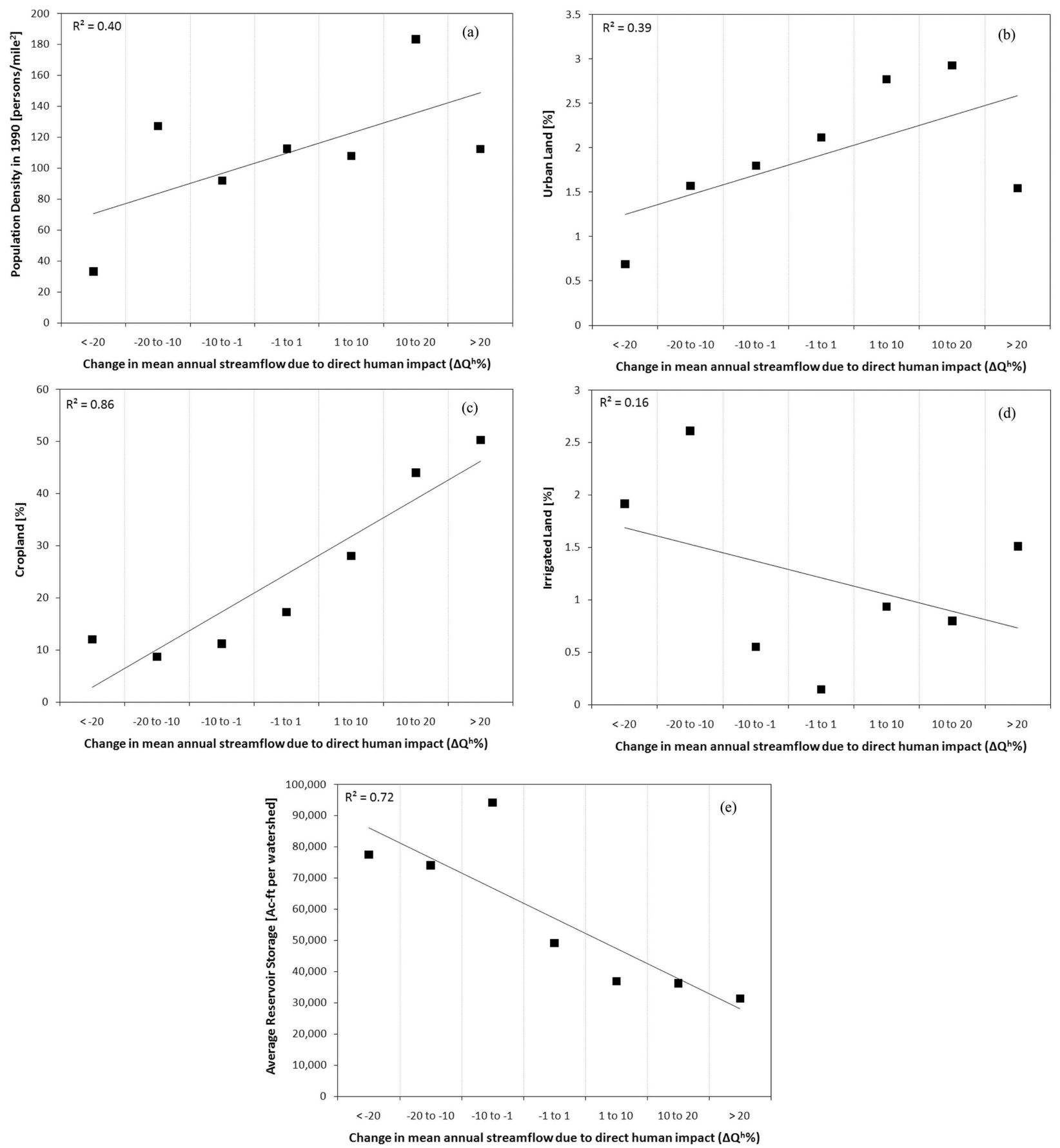

Figure 6. Comparison of the estimated $\Delta Q^{h} \%$ (seven categories) with external validation data, namely, (a) population density, (b) urban land, (c) cropland, (d) irrigated land, and (e) average reservoir storage. 


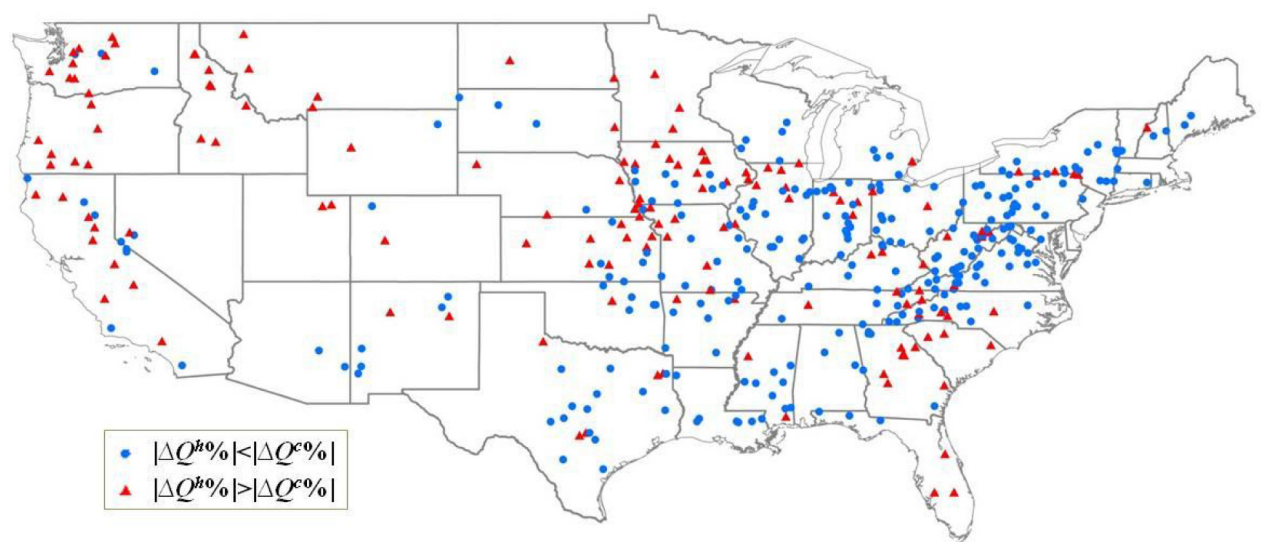

Figure 7. The spatial distribution of the relative role between direct human and climate factors.

triangles represent the gauges where the magnitude of direct human-induced MAS change is larger than that induced by climate change. In the High Plains and western United States, humans play a more important role than climate change. Along the Pacific coast of the United States, a primarily arid region with a large and growing population, Barnett et al. [2008] found that $60 \%$ of the climate-related trends of river flow, winter air temperature, and snow pack between 1950 and 1999 are human induced. Among the 431 watersheds, there are 146 watersheds where $\left|\Delta Q^{h \%}\right|$ is larger than $\left|\Delta Q^{c \%}\right|$.

[32] Figure 8a shows the percentage of net streamflow change $(\Delta Q \%)$. Figures $8 \mathrm{~b}$ and $8 \mathrm{c}$ show the spatial distribution of climate-induced $\left(\Delta Q^{c} \%\right)$ and direct humaninduced $\left(\Delta Q^{h \%}\right)$ percentages of MAS change, respectively. The impact of the climate on MAS is homogeneous, with most of the 413 watersheds showing an increasing trend in MAS (Figure 8b). Only a few watersheds in Florida and in the West Coast region showed that climate change reduces the amount of MAS. This is consistent with the findings by previous studies [e.g., Small et al., 2006]. The greatest climate impact is in the southwest regions of the United States where climate change causes $60 \%-100 \%$ increase of MAS (Figure 8b). On the other hand, the impact of human activities is somewhat heterogeneous over the entire contiguous United States (Figure 8c). Nonetheless, spatial patterns are clear at the regional scale; for example, human impact increased MAS in more watersheds in the Midwest. This is consistent with the findings by Schilling et al. [2010], who found that the runoff coefficient increased by $32 \%$ because of land use change in the Upper Mississippi River Basin. The greatest human impacts in the selected watersheds are in the High Plains, where the direct human-induced streamflow decrease is about $30 \%$ and up to $120 \%$ (Figure 8c). Human impacts decreased MAS in more watersheds in the southeastern United States.

[33] To further investigate if the estimated climate- and direct human-induced changes can be explained by other factors, the estimated $\left|\Delta Q^{c} \%\right|$ and $\left|\Delta Q^{h \%}\right|$ are plotted against climate dryness index and evaporation ratio, respectively (Figure 9). From Figures 9a and 9b, even though the data points scatter when dryness index is larger than 2, both climate- and direct human-induced MAS changes increase with the dryness index, and the relationship is close to a linear trend. From Figures $9 \mathrm{c}$ and $9 \mathrm{~d}$, both climate- and direct human-induced streamflow changes increase with evaporation ratio, and an exponential trend exists, especially for the climate-induced MAS change. Thus, arid regions (i.e., water limited) are more vulnerable to climate change and direct human interferences than wet regions (i.e., energy limited).

\section{Summary and Conclusions}

[34] In this paper, a decomposition method is proposed to explicitly quantify the relative contributions of climate and direct human impacts on changes in mean annual streamflow and is applied to 413 watersheds in the contiguous United States. The decomposition method is verified with published data in over 20 watersheds, as well as independent data sets on human activities, such as population density, percent of urban, crop, and irrigated lands, and storage of reservoirs. Given the simplicity of the proposed method to separate the climate and direct human impacts on MAS, applying the method to many watersheds becomes feasible as compared to more complex hydrologic simulation models. The method can be easily extended to handle more comprehensive data sets.

[35] The proposed decomposition method hinges on the following assumptions: (1) For a watershed without direct human interferences, if the $E_{p} / P$ moves to a drier or wetter region because of climate change, $E / P$ will also change to a new region but will still follow the same Budyko-type curve as in the prechange period. (2) Precipitation and potential evaporation are assumed to be stationary during the prechange and postchange periods. The change of precipitation and potential evaporation can be due to natural climate variability at interdecadal or interannual time scales, human-induced climate change, i.e., global warming, and the feedback of human activities (such as urbanization and urban heat island effects, irrigation, and crop evapotranspiration) to climate at regional and local scales. The coupled human, climate, and hydrologic systems are complex, and the separation of total human impact on the streamflow from other factors is complicated by the interactions and feedbacks among the subsystems through physical processes. 


\begin{tabular}{|c|}
\hline$\Delta Q \%$ \\
$-90--62$ \\
$-61--23$ \\
$-22--10$ \\
$-9--4$ \\
$-3-0$ \\
$0-14$ \\
$15-31$ \\
$32-58$ \\
$59-98$ \\
$99-177$ \\
\hline
\end{tabular}
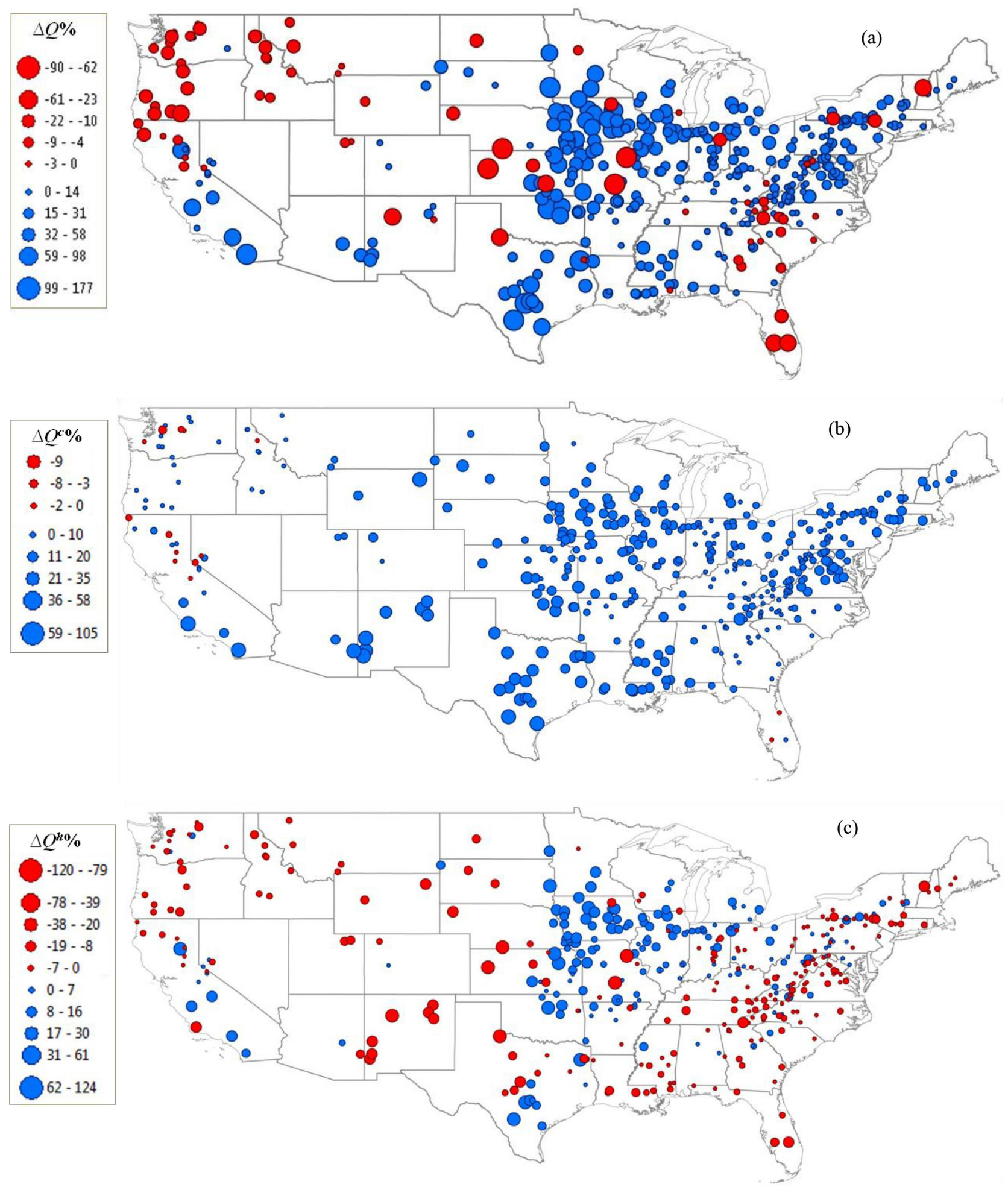

Figure 8. Spatial distribution of the direct human- and climate-induced trend on streamflow by Fu's equation: (a) $\Delta Q \%$, (b) $\Delta Q^{c} \%$, and (c) $\Delta Q^{h \%}$. 

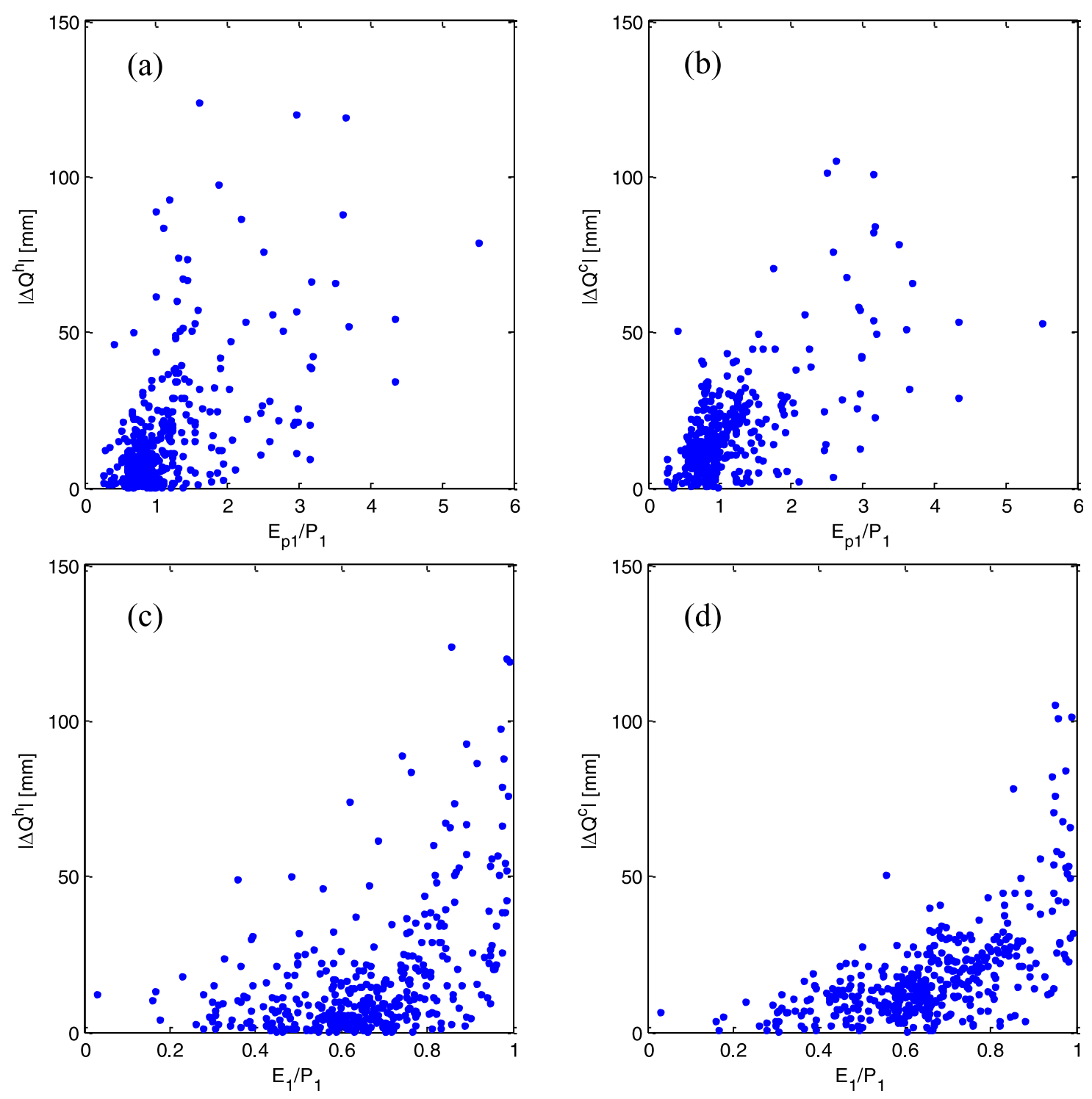

Figure 9. The estimated climate- and direct human-induced streamflow change versus $(a, b)$ climate dryness index and (c, d) evaporation ratio.

Therefore, in this paper the quantified anthropogenic streamflow change is confined to direct human impacts, and the potential indirect feedbacks of human activities to precipitation and potential evaporation change are not included.

[36] The spatial distribution of direct human- and climaterelated MAS revealed that unlike climate change, which induces increased MAS in most watersheds, the direct humaninduced MAS change is spatially heterogeneous in the contiguous United States, while strong regional patterns exist. For example, direct human impact increased the streamflow in the Midwest, while direct human impact decreased MAS in many watersheds in the High Plains and southeastern United States. The impact of climate change and human interferences on MAS in arid regions is larger than that in wet regions.

[37] When averaging across all 413 watersheds, climate change plays a bigger role than direct human impact. However, the MOPEX data set is constructed to contain watersheds that have undergone minimal human activities in the United States and has been utilized under the assumption that it includes only gauges believed to be unaffected by upstream regulations. Our study shows that human impact is likely to be more significant in some of the watersheds, such as those with urban areas and extensively irrigated agricultural watersheds. As an extension to this research, one can apply the decomposition method to other watersheds where human activities are significant and map the human interferences to streamflow in the contiguous United States. The specific human activities that affected the streamflow can be identified for each watershed, such as land use change, surface and groundwater water withdrawal, return flow, and water diversion. Moreover, projections of future climate change from general circulation models or regional climate models can be combined with the decomposition method to project the climate change impact on streamflow in the future. 
[38] Acknowledgments. Partial financial support for the first author was provided by the Office of Research \& Commercialization at University of Central Florida. Pacific Northwest National Laboratory is operated by Battelle Memorial Institute for the U.S. Department of Energy under Contract No. DE-AC06-76RLO1830. The authors are grateful to the Associate Editor and three reviewers whose comments led to important revisions.

\section{References}

Arrigoni, A. S., M. C. Greenwood, and J. N. Moore (2010), Relative impact of anthropogenic modifications versus climate change on the natural flow regimes of rivers in the northern Rocky Mountains, United States, Water Resour. Res., 46, W12542, doi:10.1029/2010WR009162.

Barnett, T. P., et al. (2008), Human-induced changes in the hydrology of the western United States, Science, 319, 1080-1083, doi:10.1126/science. 1152538.

Brutsaert, W., and M. Parlange (1998), Hydrologic cycle explains the evaporation paradox, Nature, 396, 30.

Budyko, M. I. (1958), The Heat Balance of the Earth's Surface, U.S. Dep. of Commer., Washington, D. C.

Budyko, M. I. (1974), Climate and Life, 508 pp., Academic, New York.

Donohue, R. J., M. L. Roderick, and T. R. McVicar (2007), On the importance of including vegetation dynamics in Budyko's hydrological model, Hydrol. Earth Syst. Sci., 11, 983-995.

Donohue, R. J., M. L. Roderick, and T. R. McVicar (2010), Can dynamic vegetation information improve the accuracy of Budyko's hydrological model, J. Hydrol., 390, 23-34.

Dooge, J. C. I. (1992), Sensitivity of runoff to climate change: a Hortonian approach, Bulletin American Meteorological Society, 73(12), 2013-2024.

Duan, Q., et al. (2006), The Model Parameter Estimation Experiment (MOPEX): An overview of science strategy and major results from the second and third workshops, J. Hydrol., 320, 3-17, doi:10.1016/ j.jhydrol.2005.07.031.

Fu, B. P. (1981), On the calculation of the evaporation from land surface [in Chinese], Sci. Atmos. Sin., 5, 23-31.

Gerrits, A. M., H. H. G. Savenije, E. J. M. Veling, and L. Pfister (2009), Analytical derivation of the Budyko curve based on rainfall characteristics and a simple evaporation model, Water Resour. Res., 45, W04403, doi:10.1029/2008WR007308.

Groisman, P. Y., R. W. Knight, T. R. Karl, D. R. Easterling, B. Sun, and J. H. Lawrimore (2004), Contemporary changes of the hydrological cycle over the contiguous United States: Trends derived from in situ observations, J. Hydrometeorol., 5, 64-85.

Jones, J. (2011), Hydrologic responses to climate change: Considering geographic context and alternative hypotheses, Hydrol. Processes, 25, 1996-2000.

Jothityangkoon, C., and M. Sivapalan (2009), Framework for exploration of climatic and landscape controls on catchment water balance, with emphasis on inter-annual variability, J. Hydrol., 371, 154-168.

Karl, T. R., and R. W. Knight (1998), Secular trends of precipitation amount, frequency, and intensity in the United States, Bull. Am. Meteorol. Soc., 79, 231-241.

Karl, T. R., R. W. Knight, D. R. Easterling, and R. G. Quayle (1996), Indices of climate change for the United States, Bull. Am. Meteorol. Soc., 77, 278-292.

Krakauer, N. Y., and I. Fung (2008), Mapping and attribution of change in streamflow in the coterminous United States, Hydrol. Earth Syst. Sci., 12, 1111-1120.

Kustu, M. D., Y. Fan, and M. Rodell (2011), Possible link between irrigation in the U.S. High Plains and increased summer streamflow in the Midwest, Water Resour. Res., 47, W03522, doi:10.1029/2010WR010046.

Li, L., L. Zhang, H. Wang, J. Wang, J. Yang, D. Jiang, J. Li, and D. Qin (2007), Assessing the impact of climate variability and human activities on streamflow from the Wuding River basin in China, Hydrol. Processes, 21, 3485-3491, doi:10.1002/hyp.6485.

Lins, H. F., and J. R. Slack (1999), Streamflow trends in the United States, Geophys. Res. Lett., 26, 227-230, doi:10.1029/1998GL900291.

Luce, C. H., and Z. A. Holden (2009), Declining annual streamflow distributions in the Pacific northwest United States, 1948-2006, Geophys. Res. Lett., 36, L16401, doi:10.1029/2009GL039407.

Ma, H., D. Yang, S. K. Tan, B. Gao, and Q. Hua (2010), Impact of climate variability and human activity on streamflow decrease in the Miyun Reservoir catchment, J. Hydrol., 389, 317-324.

Ma, Z., S. Kang, L. Zhang, L. Tong, and X. Su (2008), Analysis of impacts of climate variability and human activity on streamflow for a river basin in arid region of northwest China, J. Hydrol., 352, 239-249.
McCabe, G. J., and D. M. Wolock (2002), A step increase in streamflow in the conterminous United States, Geophys. Res. Lett., 29(24), 2185, 2185, doi: 10.1029/2002GL015999.

Milly, P. C. D. (1993), An analytic solution of the stochastic storage problem applicable to soil water, Water Resour. Res., 29(11), 3755-3758, doi : 10.1029/93WR01934.

Milly, P. C. D. (1994), Climate, soil water storage, and the average annual water balance, Water Resour. Res., 30(7), 2143-2156, doi:10.1029/ 94WR00586.

Milly, P. C. D., J. Betancourt, M. Falkenmark, R. M. Hirsch, Z. W. Kundzewicz, D. P. Lettenmaier, and R. J. Stouffer (2008), Stationarity is dead: Whither water management?, Science, 319, 573-574, doi:10.1126/science.1151915.

National Atlas of the United States (2006), Major dams of the United States, in National Atlas of the United States, Reston, Va. [Available at http:// nationalatlas.gov/atlasftp.html?openChapters=chpwater\#chpwater.]

National Research Council (2002), Estimating Water Use in the United States-A New Paradigm for the National Water Use Information Program, 176 pp., Natl. Acad. Press, Washington, D. C.

Ol'dekop, E. M. (1911), On evaporation from the surface of river basins, Transactions on Meteorological Observations, Lur-evskogo, Univ. of Tartu, Tartu, Estonia.

Pike, J. G. (1964), The estimation of annual runoff from meteorological data in a tropical climate, J. Hydrol., 2, 116-123.

Porporato, A., E. Daly, and I. Rodriguez-Iturbe (2004), Soil water balance and ecosystem response to climate change, Am. Nat., 164(5), 625-632.

Potter, N. J., and L. Zhang (2009), Interannual variability of catchment water balance in Australia, J. Hydrol., 369, 120-129.

Roderick, M. L., and G. D. Farquhar (2002), The cause of decreased pan evaporation over the past 50 years, Science, 298, 1410-1411.

Rossi, A., N. Massei, B. Laignel, D. Sebag, and Y. Copard (2009), The response of the Mississippi River to climate fluctuations and reservoir construction as indicated by wavelet analysis of streamflow and suspended-sediment load, 1950-1975, J. Hydrol., 377, 237-244.

Sankarasubramanian, A., and R. M. Vogel (2002), Annual hydroclimatology of the United States, Water Resour. Res., 38(6), 1083, 1083, doi:10.1029/2001WR000619.

Sankarasubramanian, A., R. M. Vogel, and J. F. Limbrunner (2001), Climate elasticity of streamflow in the United States, Water Resour. Res., 37(6), 1771-1781, doi:10.1029/2000WR900330.

Schilling, K. E., M. K. Jha, Y.-K. Zhang, P. W. Gassman, and C. F. Wolter (2008), Impact of land use and land cover change on the water balance of a large agricultural watershed: Historical effects and future directions, Water Resour. Res., 44, W00A09, doi:10.1029/2007WR006644.

Schilling, K. E., K. Chan, H. Liu, and Y. Zhang (2010), Quantifying the effect of land use land cover change on increasing discharge in the Upper Mississippi River, J. Hydrol., 387, 343-345.

Schreiber, P. (1904), Über die Beziehungen zwischen dem Niederschlag und der Wasserführung der Flüsse in Mitteleuropa, Z. Meteorol., 21(10), 441-452.

Siebert, S., P. Döll, S. Feick, J. Hoogeveen, and K. Frenken (2007), Global map of irrigation areas, version 4.0.1, Johann Wolfgang Goethe Univ., Frankfurt am Main, Germany. [Available at http://www.fao.org/nr/ water/aquastat/irrigationmap/index10.stm.]

Slack, J. R., A. M. Lumb, and J. M. Landwehr (1993), Hydroclimatic data network (HCDN): A U.S. Geological Survey streamflow data set for the United States for the study of climate variation, 1874-1988, U.S. Geol. Surv. Open File Rep., 92-129.

Small, D., S. Islam, and R. M. Vogel (2006), Trends in precipitation and streamflow in the eastern U.S.: Paradox or perception?, Geophys. Res. Lett., 33, L03403, doi:10.1029/2005GL024995.

Szilagyi, J. (2007), On the inherent asymmetric nature of the complementary relationship of evaporation, Geophys. Res. Lett., 34, L02405, doi:10.1029/2006GL028708.

Tomer, D. M., and K. E. Schilling (2009), A simple approach to distinguish land-use and climate-change effects on watershed hydrology, J. Hydrol., 376, 24-33.

Turc, L. (1954), Le bilan d'eau des sols. Relation entre la précipitation, l'évaporation et l'écoulement, Ann. Agron., 5, 491-569.

U.S. Geological Survey (2001), Urban areas of the United States, in National Atlas of the United States, Natl. Atlas of the U. S., Reston, Va. [Available at http://nationalatlas.gov/atlasftp.html.]

U.S. Geological Survey (2010), U.S. census database, 1990, in National Atlas of the United States, Natl. Atlas of the U. S., Reston, Va. [Available at http://nationalatlas.gov/atlasftp.html.] 
Vogel, R. M. (2011), Hydromorphology, J. Water Resour. Plann. Manage., 137(2), 147-149.

Vörösmarty, C. J., P. Green, J. Salisbury, and R. B. Lammers (2000), Global water resources: Vulnerability from climate change and population growth, Science, 289, 284-288, doi:10.1126/science.289.5477.284.

Wagener, T., M. Sivapalan, P. A. Troch, B. L. McGlynn, C. J. Harman, H. V. Gupta, P. Kumar, P. S. C. Rao, N. B. Basu, and J. S. Wilson (2010), The future of hydrology: An evolving science for a changing world, Water Resour. Res., 46, W05301, doi:10.1029/2009WR008906.

Wang, D., and X. Cai (2010), Comparative study of climate and human impacts on seasonal base flow in urban and agricultural watersheds, Geophys. Res. Lett., 37, L06406, doi:10.1029/2009GL041879.

Wang, G., J. Xia, and J. Chen (2009), Quantification of effects of climate variations and human activities on runoff by a monthly water balance model: A case study of the Chaobai River basin in northern China, Water Resour. Res., 45, W00A11, doi:10.1029/2007WR006768.

Weiskel, P. K., R. M. Vogel, P. A. Steeves, P. J. Zarriello, L. A. DeSimone, and K. G. Ries (2007), Water use regimes: Characterizing direct human interaction with hydrologic systems, Water Resour. Res., 43, W04402, doi: 10.1029/2006WR005062.

Yang, D., F. Sun, Z. Liu, Z. Cong, G. Ni, and Z. Lei (2007), Analyzing spatial and temporal variability of annual water-energy balance in nonhumid regions of China using the Budyko hypothesis, Water Resour. Res., 43 , W04426, doi:10.1029/2006WR005224.

Yang, D., W. Shao, P. J. Yeh, H. Yang, S. Kanae, and T. Oki (2009), Impact of vegetation coverage on regional water balance in the nonhumid regions of China, Water Resour. Res., 45, W00A14, doi:10.1029/2008WR006948.
Yang, H., D. Yang, Z. Lei, and F. Sun (2008), New analytical derivation of the mean annual water-energy balance equation, Water Resour. Res., 44, W03410, doi:10.1029/2007WR006135.

Yokoo, Y., M. Sivapalan, and T. Oki (2008), Investigating the roles of climate seasonality and landscape characteristics on mean annual and monthly water balances, J. Hydrol., 357, 255-269.

Zhang, L., W. R. Dawes, and G. R. Walker (2001), Response of mean annual evapotranspiration to vegetation changes at catchment scale, Water Resour. Res., 37(3), 701-708, doi:10.1029/2000WR900325.

Zhang, X., L. Zhang, J. Zhao, P. Rustomji, and P. Hairsine (2008), Responses of streamflow to changes in climate and land use/cover in the Loess Plateau, China, Water Resour. Res., 44, W00A07, doi:10.1029/ 2007WR006711.

Zhang, Y. K., and K. E. Schilling (2006), Increasing streamflow and baseflow in Mississippi River since the 1940s: Effect of land use change, $J$. Hydrol., 324, 412-422, doi:10.1016/j.jhydrol.2005.09.033.

Zhao, F., Z. Xu, L. Zhang, and D. Zuo (2009), Streamflow response to climate variability and human activities in the upper catchment of the Yellow River Basin, Sci. China, Ser E, 52(11), 3249-3256, doi:10.1007/ s11431-009-0354-3.

M. Hejazi, Joint Global Change Research Institute, Pacific Northwest National Laboratory, 5825 University Research Ct., Suite 3500, College Park, MD 20740, USA.

D. Wang, Department of Civil, Environmental, and Construction Engineering, University of Central Florida, Orlando, FL 32168, USA. (dingbao. wang@ucf.edu) 